\title{
Health risks of heavy metals in contaminated soils and food crops irrigated with wastewater in Beijing, China
}

\author{
S. Khan ${ }^{\text {a,b }}$, Q. Cao ${ }^{\text {a }}$, Y.M. Zheng ${ }^{\text {a }}$, Y.Z. Huang ${ }^{\text {a }, ~ Y . G . ~ Z h u ~}{ }^{\text {a,* }}$ \\ ${ }^{a}$ Research Center for Eco-environmental Sciences, Chinese Academy of Sciences, 18 Shuangqing Road, Beijing 100085, China \\ ${ }^{\mathrm{b}}$ Department of Environmental Sciences, University of Peshawar, 25120 Peshawar, Pakistan
}

Received 20 April 2007; received in revised form 23 June 2007; accepted 26 June 2007

Long-term wastewater irrigation leads to buildup of heavy metals in soils and food crops.

\begin{abstract}
Consumption of food crops contaminated with heavy metals is a major food chain route for human exposure. We studied the health risks of heavy metals in contaminated food crops irrigated with wastewater. Results indicate that there is a substantial buildup of heavy metals in wastewater-irrigated soils, collected from Beijing, China. Heavy metal concentrations in plants grown in wastewater-irrigated soils were significantly higher $(P \leq 0.001)$ than in plants grown in the reference soil, and exceeded the permissible limits set by the State Environmental Protection Administration (SEPA) in China and the World Health Organization (WHO). Furthermore, this study highlights that both adults and children consuming food crops grown in wastewater-irrigated soils ingest significant amount of the metals studied. However, health risk index values of less than 1 indicate a relative absence of health risks associated with the ingestion of contaminated vegetables.
\end{abstract}

(C) 2007 Elsevier Ltd. All rights reserved.

Keywords: Health risk; Heavy metal; Plant uptake; Soil contamination; Wastewater irrigation

\section{Introduction}

Heavy metals are ubiquitous in the environment, as a result of both natural and anthropogenic activities, and humans are exposed to them through various pathways (Wilson and Pyatt, 2007). Wastewater irrigation, solid waste disposal, sludge applications, vehicular exhaust and industrial activities are the major sources of soil contamination with heavy metals, and an increased metal uptake by food crops grown on such contaminated soils is often observed. In general, wastewater contains substantial amounts of beneficial nutrients and toxic heavy metals, which are creating opportunities and problems for agricultural production, respectively (Chen et al., 2005; Singh et al., 2004).

\footnotetext{
* Corresponding author. Tel.: +86106293 6940; fax: +861062923563.

E-mail address: ygzhu@rcees.ac.cn (Y.G. Zhu).
}

Excessive accumulation of heavy metals in agricultural soils through wastewater irrigation, may not only result in soil contamination, but also lead to elevated heavy metal uptake by crops, and thus affect food quality and safety (Muchuweti et al., 2006). Heavy metal accumulation in soils and plants is of increasing concern because of the potential human health risks. This food chain contamination is one of the important pathways for the entry of these toxic pollutants into the human body. Heavy metal accumulation in plants depends upon plant species, and the efficiency of different plants in absorbing metals is evaluated by either plant uptake or soil-toplant transfer factors of the metals (Rattan et al., 2005).

Vegetables cultivated in wastewater-irrigated soils take up heavy metals in large enough quantities to cause potential health risks to the consumers. In order to assess the health risks, it is necessary to identify the potential of a source to introduce risk agents into the environment, estimate the amount of risk agents that come into contact with the human-environment 
boundaries, and quantify the health consequence of the exposure (Ma et al., 2006). According to the National Research Council (NRC), 1983, this process consists of four steps, hazard identification, exposure assessment, dose/response assessment, and risk characterization. Chronic level intake of toxic metals has adverse impacts on humans and the associated harmful impacts become apparent only after several years of exposure (Bahemuka and Mubofu, 1999; Ikeda et al., 2000). However, the consumption of heavy metal-contaminated food can seriously deplete some essential nutrients in the body that are further responsible for decreasing immunological defenses, intrauterine growth retardation, impaired psycho-social faculties, disabilities associated with malnutrition and high prevalence of upper gastrointestinal cancer rates (Iyengar and Nair, 2000; Türkdogan et al., 2003).

Wastewater irrigation is a widespread practice in the world and recently a number of articles have been published on wastewater-irrigated soils contaminated with heavy metals (Liu et al., 2005; Mapanda et al., 2005; Rattan et al., 2005; Rothenberg et al., 2007). However, an additional insight into metal uptake, accumulation and assessment of human health risks associated with wastewater-irrigated soils is still needed. This study was conducted to investigate the soil pollution load, to understand the appropriateness of wastewater-irrigated soils for vegetable cultivation, and to assess the metal uptake by food crops and the potential health risks associated with human consumption of food crops contaminated with heavy metals.

\section{Materials and methods}

\subsection{Study area}

The study area is located in southwest of Tongzhou District, Beijing, China. The area has a continental monsoon climate, characterized by a wide seasonal variation in annual rainfall $(620 \mathrm{~mm})$, cold and dry winters, and hot and rainy summers. Being the capital of China, Beijing City is generating a huge amount of wastewater from domestic, commercial and industrial sectors. In metropolitan areas, the wastewater is biologically treated and mainly reused in agricultural production during the irrigation season. The wastewater irrigation commenced in the early 1960s and is still being practiced to meet the needs of irrigation in agriculture around the region. The soils in this area are mainly cinnamon soil (Argosols) and fluvo-aquic soil (Cambosols). The food crops are mainly wheat, corn, and vegetable (Liu et al., 2005).

\subsection{Soil sampling and characterization}

Wastewater-irrigated and reference soils were collected in September 2005. At each site, soils at four locations were randomly sampled from the upper horizon $(0-20 \mathrm{~cm})$ and bulked together to form a composite sample. After transportation to the laboratory, soil was air-dried and sieved through a $<2 \mathrm{~mm}$ mesh, and then sealed in Kraft paper envelopes until analysis. Sub-samples were used to measure the physico-chemical properties according to standard procedures (Table 1). The soil $\mathrm{pH}$ was measured with $\mathrm{H}_{2} \mathrm{O}$ (1:2.5 ratio, dry $\mathrm{wt} / \mathrm{v})$. For the heavy metal concentrations, soil was extracted by aqua regia at $160^{\circ} \mathrm{C}$ and then metal concentrations in the digests were determined by the inductively coupled plasma-optical emission spectrometry (ICP-OES, Perkin-Elmer OPTIMA-2000, USA). Water soluble organic carbon and its fractions including humic acid carbon and fulvic acid carbon were measured as described by Chen et al. (2004).

\subsection{Food crop sampling and analysis}

Standing food crop samples including radish (Raphanus sativus $\mathrm{L}$ ), maize (Zea mays), green cabbage (Brassica juncea L), spinach (Spinacia oleracea $\mathrm{L}$ ), cauliflower (Brassica oleracea L), turnip (Brassica napus), and lettuce (Lactuca sativa $\mathrm{L}$ ) were also collected from the same sites where soils were collected. At harvest, plants were divided into shoots and roots, and properly washed with deionized water to remove all visible soil particles. Plant samples were prepared according to the procedure described in our previous work (Khan et al., 2006), and heavy metals were measured using graphite furnace atomic absorption spectrophotometer (GF-AAS, Shimadzu-6300, Japan).

\subsection{Quality control}

The blank reagent and standard reference soil and plant materials (from the National Research Center for Standards in China) were included in each sample batch to verify the accuracy and precision of the digestion procedure and subsequent analyses.

\subsection{Data analysis}

\subsubsection{Transfer factor}

Metal concentrations in the extracts of soils and plants were calculated on the basis of dry weight. The plant concentration factor (PCF) was calculated as follows:

Table 1

Characteristics of wastewater-irrigated and reference soils collected from the study area

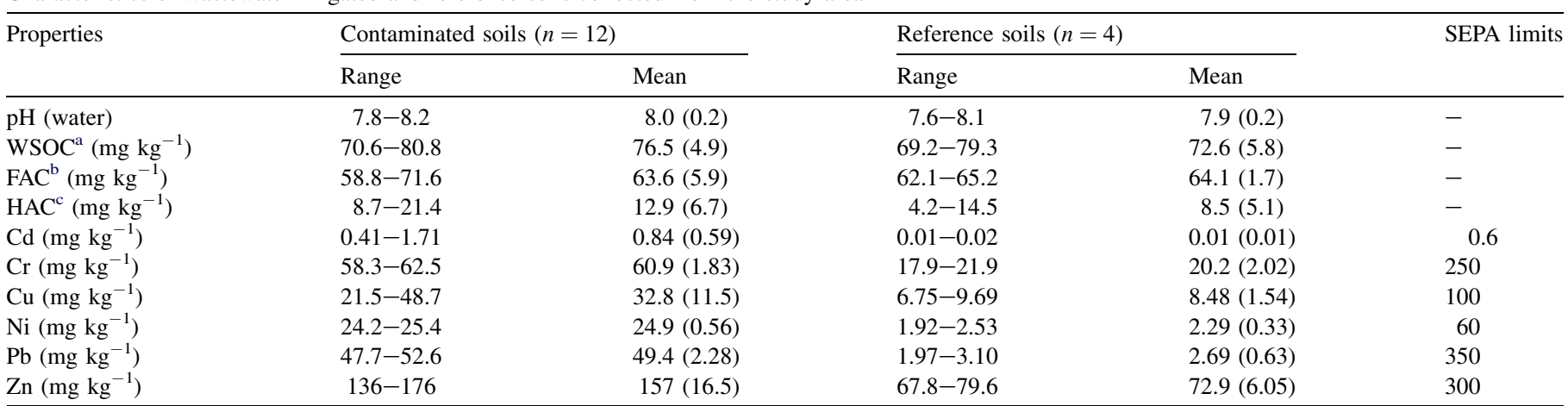

Numbers in parenthesis indicate the standard deviation.

${ }^{a}$ Water soluble organic carbon.

b Fulvic acid carbon.

${ }^{c}$ Humic acid carbon. 
$\mathrm{PCF}=\frac{C_{\text {plant }}}{C_{\text {soil }}} \quad($ Cui et al., 2005)

where $C_{\text {plant }}$ and $C_{\text {soil }}$ represent the heavy metal concentration in extracts of plants and soils on dry weight basis, respectively.

\subsubsection{Pollution load index}

The degree of soil pollution for each metal was measured using the pollution load index (PLI) technique depending on soil metal concentrations. The following modified equation was used to assess the PLI level in soils.

PLI $=\frac{C_{\text {soil }}(\text { Samples })}{C_{\text {reference }}(\text { References })} \quad($ Liu et al., 2005)

where $C_{\text {soil }}$ (Samples) and $C_{\text {reference }}$ (Reference) represent the heavy metal concentrations in the wastewater-irrigated and reference soils, respectively.

\subsubsection{Daily intake of metals}

The daily intake of metals (DIM) was determined by the following equation.

$\mathrm{DIM}=\frac{C_{\text {metal }} \times C_{\text {factor }} \times D_{\text {food intake }}}{B_{\text {average weight }}}$

where $C_{\text {metal }}, C_{\text {factor }}, D_{\text {food intake }}$ and $B_{\text {average weight }}$ represent the heavy metal concentrations in plants $\left(\mathrm{mg} \mathrm{kg}^{-1}\right)$, conversion factor, daily intake of vegetables and average body weight, respectively. The conversion factor 0.085 was used to convert fresh green vegetable weight to dry weight, as described by Rattan et al. (2005). The average daily vegetable intakes for adults and children were considered to be 0.345 and $0.232 \mathrm{~kg}_{\text {person }}{ }^{-1} \mathrm{day}^{-1}$, respectively, while the average adult and child body weights were considered to be 55.9 and $32.7 \mathrm{~kg}$, respectively, as used in previous studies (Ge, 1992; Wang et al., 2005).

\subsubsection{Health risk index}

The health risk index (HRI) for the locals through the consumption of contaminated vegetables was assessed based on the food chain and the reference oral dose (RfD) for each metal. The HRI $<1$ means the exposed population is assumed to be safe.

$\mathrm{HRI}=\frac{\mathrm{DIM}}{\mathrm{RfD}} \quad(\mathrm{US}-\mathrm{EPA}, 2002)$

The data were statistically analyzed using a statistical package SPSS 11.5. The measures were expressed in terms of means, while the figures also presented with the mean values and standard errors of triplicates. Statistical significance was computed using Pair-Samples $T$-Test, with a significance level of $P<0.05$.

\section{Results}

\subsection{Soil contamination}

Table 1 summarizes the physicochemical characteristics of all samples, including both wastewater-irrigated and reference soils. Soil pH was not significantly affected by the wastewater irrigation. In the wastewater-irrigated soils, the water soluble organic carbon values were not significantly increased compared with the reference soils. The water soluble organic carbon contents ranged from $70.6 \mathrm{mg} \mathrm{kg}^{-1}$ to $80.8 \mathrm{mg} \mathrm{kg}^{-1}$ in wastewater-irrigated soils, while the corresponding values for reference soils were between $69.2 \mathrm{mg} \mathrm{kg}^{-1}$ and $79.3 \mathrm{mg} \mathrm{kg}^{-1}$. Similarly, the fulvic acid fraction of water soluble organic carbon was not significantly different, and ranged from $58.8 \mathrm{mg} \mathrm{kg}^{-1}$ to $71.6 \mathrm{mg} \mathrm{kg}^{-1}$ in wastewater-irrigated soils, and from $62.1 \mathrm{mg} \mathrm{kg}^{-1}$ to $65.2 \mathrm{mg} \mathrm{kg}^{-1}$ in the reference soils. However, humic acid values were significantly increased $(P \leq 0.05)$ in wastewater-irrigated soils, ranged from $8.7 \mathrm{mg} \mathrm{kg}^{-1}$ to $21.4 \mathrm{mg} \mathrm{kg}^{-1}$. This increase in the humic acid contents may be due to the presence of humic substances in wastewater.

Across the study area, a wide range of soil heavy metal concentrations were observed (Table 1). In the wastewater-irrigated soils, heavy metal $(\mathrm{Cd}, \mathrm{Cr}, \mathrm{Cu}, \mathrm{Ni} \mathrm{Pb}$, and $\mathrm{Zn})$ concentrations were significantly higher $(P<0.001)$ compared with the reference soils. The results indicated that all the metal concentrations except for $\mathrm{Cd}$, were below the Environmental Quality Standards set by the State Environmental Protection Administration (SEPA, 1995) for soils in China (Table 1). However, there was substantial buildup of $\mathrm{Cd}, \mathrm{Cr}, \mathrm{Cu}, \mathrm{Ni}$, $\mathrm{Pb}$ and $\mathrm{Zn}$ in the wastewater-irrigated soils compared to the reference soils. On average, the PLI indices for $\mathrm{Cd}, \mathrm{Cr}, \mathrm{Cu}$, $\mathrm{Ni}, \mathrm{Pb}$ and $\mathrm{Zn}$ were 84.0, 3.0, 3.9, 10.9, 18.4, and 2.1, respectively, using the reference soil concentrations of this study.

\subsection{Heavy metals in food crops}

Heavy metal concentrations in the edible plant portions of plants grown in wastewater-irrigated soils were compared with the plants grown in reference soils, and the standards set for vegetables and fruits in China. According to the SEPA, 2005, the maximum permissible limits of $\mathrm{Cd}, \mathrm{Cr}, \mathrm{Cu}$, $\mathrm{Ni}, \mathrm{Pb}$, and $\mathrm{Zn}$ for vegetables and fruits are $0.1-0.2,0.5$, 20, 10, 9, and $100 \mathrm{mg} \mathrm{kg}^{-1}$, respectively, on a dry weight basis. The $\mathrm{Cd}$ concentrations ranged from $0.39 \mathrm{mg} \mathrm{kg}^{-1}$ to $0.93 \mathrm{mg} \mathrm{kg}^{-1}$ (Fig. 1a) in the plants grown in wastewater-irrigated soils, and were significantly higher $(P \leq 0.001)$ than plants grown in the reference soil. In all plant samples, concentrations of $\mathrm{Cd}$ and $\mathrm{Cr}$ exceeded the SEPA limits. Similarly, the Ni concentrations were significantly higher $(P<0.01)$ especially the samples of Raphanus sativus L., Zea mays, Brassica juncea L., Brassica oleracea L, Brassica napus, and Lactuca sativa $\mathrm{L}$ than plants grown in the reference soils, and exceeded the SEPA limit for $\mathrm{Ni}\left(10 \mathrm{mg} \mathrm{kg}^{-1}\right)$. The $\mathrm{Pb}$ concentrations varied between $2.55 \mathrm{mg} \mathrm{kg}^{-1}$ and $4.50 \mathrm{mg} \mathrm{kg}^{-1}$, in the plants grown in wastewater-irrigated soils and were significantly higher $(P \leq 0.001)$ than plants grown in the reference soil, and exceeded the SEPA limit for $\mathrm{Pb}$ $\left(9 \mathrm{mg} \mathrm{kg}{ }^{-1}\right)$. However, $\mathrm{Cu}$ and $\mathrm{Zn}$ concentrations were substantially lower than the SEPA limits in all food crops grown in wastewater-irrigated soils (Fig. 1) but still significantly higher than the plants grown in the reference soil. The trends of heavy metal concentrations in different vegetables were in the order of Lactuca sativa $\mathrm{L}>$ Brassica spp. $>$ Raphanus sativus L. > Spinacia spp.

\subsection{Heavy metal transfer from soils to food crops}

The PCF values between wastewater-irrigated and reference soils were not significantly different. The mean values of PCF for heavy metals including $\mathrm{Cd}, \mathrm{Cr}, \mathrm{Cu}, \mathrm{Ni}, \mathrm{Pb}$, and $\mathrm{Zn}$ ranged from 0.51 to $1.47,0.12$ to $0.29,0.32$ to 0.51 , 0.36 to $0.57,0.04$ to 0.11 , and 0.21 to 0.41 , respectively 
(a)

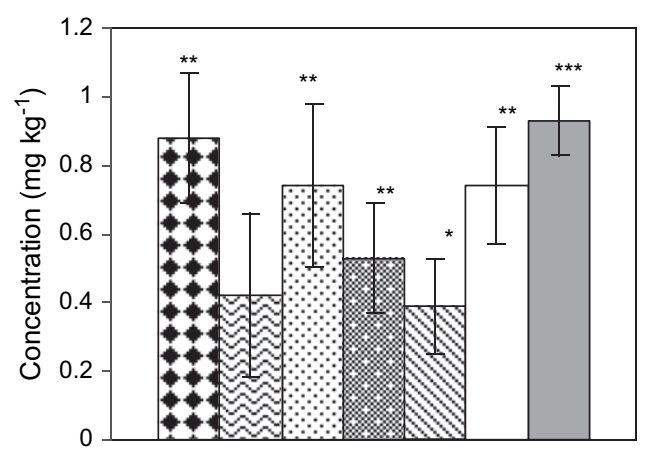

(c)

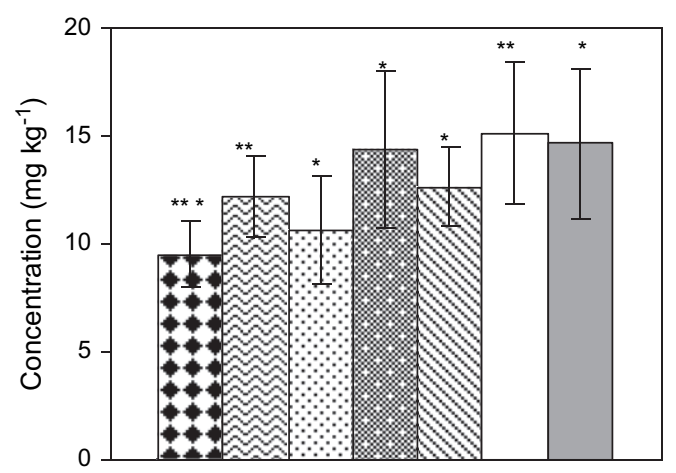

(e)

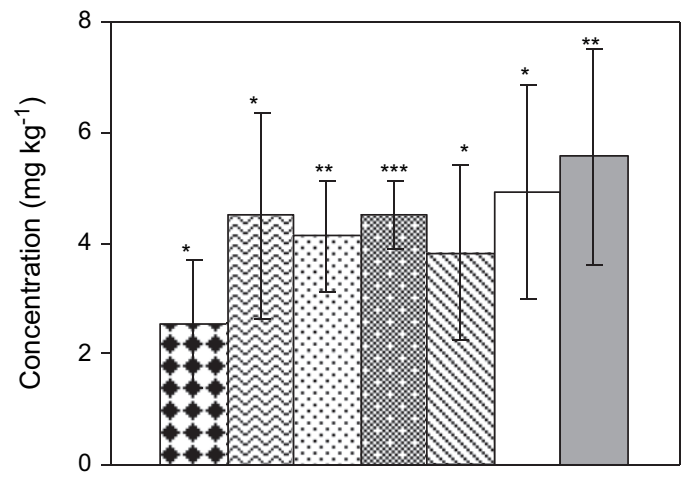

(b)

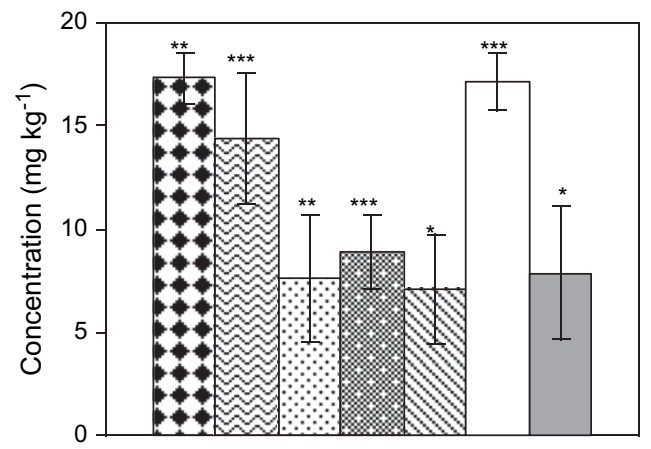

(d)

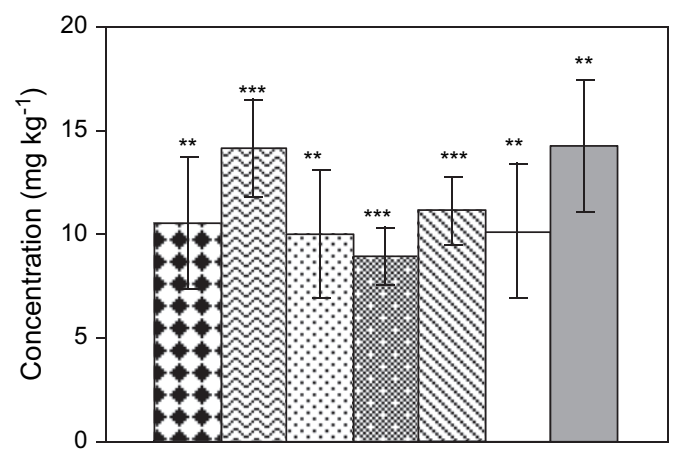

(f)

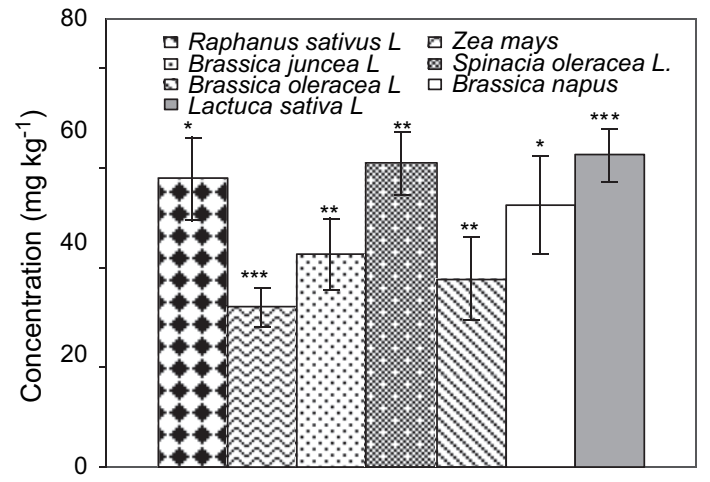

Plant types

Fig. 1. Heavy metal concentrations (dry weight basis) in the edible parts of plants grown in wastewater-contaminated soils: (a) $\mathrm{Cd}$; (b) $\mathrm{Cr}$; (c) $\mathrm{Cu}$; (d) $\mathrm{Ni}$; (e) $\mathrm{Pb}$; and (f) $\mathrm{Zn}$. The error bars indicate the standard deviation while the asterisks indicate significant differences in heavy metal concentrations between plants grown in wastewater-irrigated and reference soils, at $P<0.05(*), P<0.01(* *)$ and $P<0.001(* * *)$, respectively.

(Table 2). The trends of PCF for heavy metals in different vegetables were in the order of $\mathrm{Cd}>\mathrm{Ni}>\mathrm{Cu}>\mathrm{Zn}>\mathrm{Cr}>\mathrm{Pb}$. Similarly, we performed Pearson's correlation analysis to identify the relationships between the metal concentrations in soils and edible parts of the plants (Table 3). For $\mathrm{Cd}, \mathrm{Cu}$, $\mathrm{Pb}$, and $\mathrm{Zn}$, significant positive correlations were detected between heavy metal concentrations in soils and plants.

\subsection{Daily intake of metals through food chain and human health risks}

The daily intake of heavy metals was estimated according to the average vegetable consumption. The estimated DIM through the food chain is given in Table 4, for both adults and children.
The DIM values for heavy metals were significantly high through the consumption of food crops grown in wastewater-irrigated soils. The highest intakes of $\mathrm{Cd}, \mathrm{Cr}, \mathrm{Cu}, \mathrm{Ni}, \mathrm{Pb}$, and $\mathrm{Zn}$ were from the consumption of Lactuca sativa $\mathrm{L}$, Raphanus sativus L, Brassica napus, Lactuca sativa L, and Spinacia oleracea L., respectively, grown in wastewater-irrigated soils for both adults and children. The HRI of metals through the consumption of vegetables for both adults and children is given in Table 4 . The $\mathrm{HRI}$ of $\mathrm{Cd}, \mathrm{Cr}, \mathrm{Cu}, \mathrm{Ni}, \mathrm{Pb}$, and $\mathrm{Zn}$ ranged from $4.9 \mathrm{E}-1$ to $2.0 \mathrm{E}-1$, $6.0 \mathrm{E}-3$ to $2.0 \mathrm{E}-3,1.6 \mathrm{E}-2$ to $1.0 \mathrm{E}-2,3.8 \mathrm{E}-1$ to $2.3 \mathrm{E}-1,8.3 \mathrm{E}-2$ to $3.8 \mathrm{E}-2$, and $9.2 \mathrm{E}-2$ to $1.1 \mathrm{E}-1$, respectively for adults, while ranged from $5.6 \mathrm{E}-1$ to $2.3 \mathrm{E}-1,7.0 \mathrm{E}-3$ to $3.0 \mathrm{E}-3,1.8 \mathrm{E}-2$ to $1.1 \mathrm{E}-2,4.3 \mathrm{E}-1$ to $2.7 \mathrm{E}-1,9.5 \mathrm{E}-2$ to $4.4 \mathrm{E}-2$, and $8.6 \mathrm{E}-2$ to $1.1 \mathrm{E}-1$, respectively for children. 
Table 2

Heavy metal transfer factors (on dry weight basis) for plants grown in wastewater-irrigated soils

\begin{tabular}{|c|c|c|c|c|c|c|c|}
\hline Plants & Values & $\mathrm{Cd}$ & $\mathrm{Cr}$ & $\mathrm{Cu}$ & $\mathrm{Ni}$ & $\mathrm{Pb}$ & $\mathrm{Zn}$ \\
\hline \multirow[t]{2}{*}{ Raphanus sativus $\mathrm{L}(n=8)$} & Range & $0.69-2.14$ & $0.21-0.38$ & $0.16-0.46$ & $0.27-0.51$ & $0.02-0.08$ & $0.36-0.43$ \\
\hline & Mean & $1.29(0.62)$ & $0.29(0.07)$ & $0.32(0.13)$ & $0.42(0.11)$ & $0.04(0.03)$ & $0.41(0.03)$ \\
\hline \multirow{2}{*}{ Zea mays $(n=6)$} & Range & $0.23-1.01$ & $0.20-0.29$ & $0.25-0.49$ & $0.46-0.64$ & $0.05-0.13$ & $0.16-0.25$ \\
\hline & Mean & $0.51(0.37)$ & $0.24(0.04)$ & $0.40(0.11)$ & $0.57(0.08)$ & $0.09(0.03)$ & $0.21(0.04)$ \\
\hline \multirow[t]{2}{*}{ Brassica juncea L $(n=10)$} & Range & $0.30-1.80$ & $0.09-0.18$ & $0.27-0.39$ & $0.26-0.52$ & $0.06-0.10$ & $0.24-0.30$ \\
\hline & Mean & $1.21(0.65)$ & $0.13(0.04)$ & $0.34(0.05)$ & $0.40(0.11)$ & $0.08(0.01)$ & $0.27(0.03)$ \\
\hline \multirow[t]{2}{*}{ Spinacia oleracea L. $(n=5)$} & Range & $0.34-1.29$ & $0.11-0.17$ & $0.40-0.48$ & $0.31-0.40$ & $0.08-0.10$ & $0.32-0.49$ \\
\hline & Mean & $0.81(0.42)$ & $0.15(0.02)$ & $0.45(0.04)$ & $0.36(0.04)$ & $0.09(0.01)$ & $0.39(0.07)$ \\
\hline \multirow[t]{2}{*}{ Brassica oleracea L. $(n=7)$} & Range & $0.32-0.94$ & $0.08-0.17$ & $0.30-0.50$ & $0.40-0.51$ & $0.04-0.11$ & $0.21-0.31$ \\
\hline & Mean & $0.56(0.26)$ & $0.12(0.04)$ & $0.41(0.09)$ & $0.45(0.05)$ & $0.08(0.03)$ & $0.24(0.04)$ \\
\hline \multirow[t]{2}{*}{ Brassica napus $(n=8)$} & Range & $0.54-1.80$ & $0.24-0.33$ & $0.35-0.85$ & $0.27-0.52$ & $0.07-0.13$ & $0.24-0.48$ \\
\hline & Mean & $1.11(0.54)$ & $0.28(0.04)$ & $0.51(0.24)$ & $0.41(0.11)$ & $0.10(0.03)$ & $0.34(0.10)$ \\
\hline \multirow[t]{2}{*}{ Lactuca sativa $\mathrm{L}(n=12)$} & Range & $0.48-2.24$ & $0.08-0.20$ & $0.38-0.70$ & $0.44-0.73$ & $0.07-0.13$ & $0.34-0.53$ \\
\hline & Mean & $1.47(0.75)$ & $0.13(0.05)$ & $0.48(0.15)$ & $0.57(0.12)$ & $0.11(0.03)$ & $0.41(0.09)$ \\
\hline
\end{tabular}

Numbers in parenthesis indicate the standard deviation.

\section{Discussion}

The application of wastewater has led to changes in some soil physicochemical characteristics and heavy metal uptake by food crops, particularly vegetables. The soil $\mathrm{pH}$ changes depend on $\mathrm{pH}$ of the wastewater used for irrigation, and the soil $\mathrm{pH}$ has a great influence on the mobility and bioavailability of heavy metals (Nigam et al., 2001). The results showed that wastewater application dropped soil $\mathrm{pH}$ by $0.1-0.2$ units compared the wastewater-irrigated soil to the reference soil. The water soluble organic carbon was increased by $5.4 \%$, while its humic acid fraction increased by $51.8 \%$, in wastewater-irrigated soils. This increase in the soil organic carbons may affect the availability of heavy metals. These results agreed with the findings of previous studies (Mapanda et al., 2005; Rattan et al., 2005). Furthermore, our results showed that continuous wastewater irrigation led to elevated levels of heavy metals in the soils and in edible parts of food crops. Heavy metal accumulation by vegetables is a cause of serious concern due to the potential public health impacts (Bi et al., 2006; Cui et al., 2005).

In this study area, soil contamination with metals is mainly due to wastewater irrigation, application of sludge in the farmlands, and possible atmospheric deposition. The ANOVA analysis showed that the concentrations of individual heavy metals in wastewater-irrigated soils were significantly higher $(P<0.001)$ than the reference soils, indicating that the wastewater irrigation has increased the heavy metal concentrations in soils. Similar results were also found in the previous studies (Liu et al., 2005). The distribution of metals in farmlands at each site was mainly affected by the location of the farmland and irrigation time. Those farmlands close to the main channel and irrigated with wastewater for $30-45$ years, showed the highest level of contamination. Lucho-Contantino et al., 2005 observed a linear increase of heavy metal concentrations with the irrigation time. Except for $\mathrm{Cd}$, all selected metals were below and/or within SEPA permissible limits in wastewater-irrigated soils.

Results from present and previous studies (Liu et al., 2005; Muchuweti et al., 2006; Sharma et al., 2007) demonstrate that the plants grown on wastewater-irrigated soils contaminated with heavy metals, and pose a major health concern. All food crops studied were contaminated with $\mathrm{Cd}, \mathrm{Cr}$, and $\mathrm{Ni}$, and partially and/or totally exceeded the permissible limits set by SEPA and WHO. In general, the heavy metal concentrations in plants, particularly, $\mathrm{Cr}, \mathrm{Cu}, \mathrm{Pb}$, and $\mathrm{Zn}$ were lower, and the $\mathrm{Cd}$ value was higher than those reported by Liu et al. (2005). Heavy metal concentrations were lower than the corresponding metal concentrations, detected in the plants grown in wastewater-irrigated soils in India (Sharma et al., 2007). However, results from this study agreed with the data reported by Rattan et al. (2005).

Typically, the soil-to-plant transfer factor is one of the key components of human exposure to metals through the food

Table 3

Pearson's correlation coefficients $(r)$ between the heavy metal concentrations in soils and plants

\begin{tabular}{lccccc}
\hline Plants & $\mathrm{Cd}$ & $\mathrm{Cr}$ & $\mathrm{Cu}$ & $\mathrm{Ni}$ & $\mathrm{Pb}$ \\
\hline Raphanus sativus $\mathrm{L}$ & 0.82 & -0.74 & -0.83 & -0.16 & -0.48 \\
Zea mays & $0.87^{*}$ & 0.28 & 0.29 & -0.36 & -0.89 \\
Brassica juncea $\mathrm{L}$ & -0.66 & 0.59 & $0.99^{*}$ & -0.85 & $0.94^{* *}$ \\
Spinacia oleracea $\mathrm{L}$ & 0.29 & -0.09 & $0.99^{* *}$ & -0.94 & 0.73 \\
Brassica oleracea $\mathrm{L}$ & $0.87^{*}$ & -0.72 & 0.95 & 0.56 & 0.97 .9 \\
Brassica napus & 0.78 & -0.52 & 0.10 & 0.10 & 0.26 \\
Lactuca sativa $\mathrm{L}$ & $0.86^{*}$ & -0.75 & 0.67 & -0.78 & $0.96^{*}$ \\
\end{tabular}

**Correlation is significant at the 0.01 level (2-tailed). *Correlation is significant at the 0.05 level (2-tailed). 
Table 4

DIM and HRI for individual heavy metals caused by the consumption of different selected vegetables grown in wastewater-irrigated soils

\begin{tabular}{|c|c|c|c|c|c|c|c|c|}
\hline Plants & Individuals & & $\mathrm{Cd}$ & $\mathrm{Cr}$ & $\mathrm{Cu}$ & $\mathrm{Ni}$ & $\mathrm{Pb}$ & $\mathrm{Zn}$ \\
\hline \multirow[t]{4}{*}{ Raphanus sativus $\mathrm{L}(n=8)$} & \multirow[t]{2}{*}{ Adults } & DIM & $5.0 \mathrm{E}-4$ & $9.0 \mathrm{E}-3$ & $5.0 \mathrm{E}-3$ & $6.0 \mathrm{E}-3$ & $1.0 \mathrm{E}-3$ & $3.0 \mathrm{E}-2$ \\
\hline & & HRI & 4.6E-1 & $6.0 \mathrm{E}-3$ & $1.0 \mathrm{E}-2$ & $2.8 \mathrm{E}-1$ & $3.8 \mathrm{E}-2$ & $1.0 \mathrm{E}-1$ \\
\hline & \multirow[t]{2}{*}{ Children } & DIM & $5.0 \mathrm{E}-4$ & $1.0 \mathrm{E}-2$ & $6.0 \mathrm{E}-2$ & $6.0 \mathrm{E}-3$ & $2.0 \mathrm{E}-3$ & $3.5 \mathrm{E}-2$ \\
\hline & & HRI & $5.3 \mathrm{E}-1$ & $5.0 \mathrm{E}-4$ & $1.1 \mathrm{E}-2$ & $3.2 \mathrm{E}-1$ & $4.4 \mathrm{E}-2$ & $1.2 \mathrm{E}-1$ \\
\hline \multirow[t]{4}{*}{ Brassica juncea L $(n=10)$} & \multirow[t]{2}{*}{ Adults } & DIM & $4.0 \mathrm{E}-4$ & $4.0 \mathrm{E}-3$ & $6.0 \mathrm{E}-3$ & $5.0 \mathrm{E}-3$ & $2.0 \mathrm{E}-3$ & $2.2 \mathrm{E}-2$ \\
\hline & & HRI & 3.9E-1 & $3.0 \mathrm{E}-3$ & $1.1 \mathrm{E}-2$ & $2.6 \mathrm{E}-1$ & $6.2 \mathrm{E}-2$ & 7.5E-2 \\
\hline & \multirow[t]{2}{*}{ Children } & DIM & $4.0 \mathrm{E}-4$ & $3.0 \mathrm{E}-3$ & $6.0 \mathrm{E}-3$ & $6.0 \mathrm{E}-3$ & $2.0 \mathrm{E}-3$ & $2.6 \mathrm{E}-2$ \\
\hline & & HRI & 4.4E-1 & $5.0 \mathrm{E}-4$ & $1.3 \mathrm{E}-2$ & $3.0 \mathrm{E}-1$ & 7.1E-2 & $8.6 \mathrm{E}-2$ \\
\hline \multirow[t]{4}{*}{ Spinacia oleracea L. $(n=5)$} & \multirow[t]{2}{*}{ Adults } & DIM & $3.0 \mathrm{E}-4$ & $5.0 \mathrm{E}-3$ & $8.0 \mathrm{E}-3$ & $5.0 \mathrm{E}-3$ & $2.0 \mathrm{E}-3$ & $3.2 \mathrm{E}-2$ \\
\hline & & HRI & $2.8 \mathrm{E}-1$ & $3.0 \mathrm{E}-3$ & $1.5 \mathrm{E}-2$ & $2.3 \mathrm{E}-1$ & $6.7 \mathrm{E}-2$ & $1.1 \mathrm{E}-1$ \\
\hline & \multirow[t]{2}{*}{ Children } & DIM & $3.0 \mathrm{E}-4$ & $5.0 \mathrm{E}-3$ & $9.0 \mathrm{E}-3$ & $5.0 \mathrm{E}-3$ & $3.0 \mathrm{E}-3$ & $3.7 \mathrm{E}-2$ \\
\hline & & HRI & $3.2 \mathrm{E}-1$ & $4.0 \mathrm{E}-3$ & $1.7 \mathrm{E}-2$ & 2.7E-1 & 7.7E-2 & $1.2 \mathrm{E}-1$ \\
\hline \multirow[t]{4}{*}{ Brassica oleracea $\mathrm{L}(n=7)$} & \multirow[t]{2}{*}{ Adults } & DIM & $2.0 \mathrm{E}-4$ & $4.0 \mathrm{E}-3$ & 7.0E-3 & $6.0 \mathrm{E}-3$ & $2.0 \mathrm{E}-3$ & $2.0 \mathrm{E}-2$ \\
\hline & & HRI & $2.0 \mathrm{E}-1$ & $2.0 \mathrm{E}-3$ & $1.3 \mathrm{E}-2$ & $2.9 \mathrm{E}-1$ & $5.7 \mathrm{E}-2$ & $6.6 \mathrm{E}-2$ \\
\hline & \multirow[t]{2}{*}{ Children } & DIM & $2.0 \mathrm{E}-4$ & $4.0 \mathrm{E}-3$ & $8.0 \mathrm{E}-3$ & $7.0 \mathrm{E}-3$ & $2.0 \mathrm{E}-3$ & $2.3 \mathrm{E}-2$ \\
\hline & & HRI & 2.3E-1 & $3.0 \mathrm{E}-3$ & $1.5 \mathrm{E}-2$ & 3.3E-1 & $6.6 \mathrm{E}-2$ & $7.6 \mathrm{E}-2$ \\
\hline \multirow[t]{4}{*}{ Brassica napus $(n=8)$} & \multirow[t]{2}{*}{ Adults } & DIM & $4.0 \mathrm{E}-4$ & $9.0 \mathrm{E}-3$ & $8.0 \mathrm{E}-3$ & $5.0 \mathrm{E}-3$ & $3.0 \mathrm{E}-3$ & $2.8 \mathrm{E}-2$ \\
\hline & & HRI & $3.9 \mathrm{E}-1$ & $6.0 \mathrm{E}-3$ & $1.6 \mathrm{E}-2$ & $2.7 \mathrm{E}-1$ & $7.4 \mathrm{E}-2$ & $9.2 \mathrm{E}-2$ \\
\hline & \multirow[t]{2}{*}{ Children } & DIM & $4.0 \mathrm{E}-4$ & $1.0 \mathrm{E}-2$ & $9.0 \mathrm{E}-3$ & $6.0 \mathrm{E}-3$ & $3.0 \mathrm{E}-3$ & $3.2 \mathrm{E}-2$ \\
\hline & & HRI & 4.4E-1 & $7.0 \mathrm{E}-3$ & $1.8 \mathrm{E}-2$ & $3.1 \mathrm{E}-1$ & 8.5E-2 & $1.1 \mathrm{E}-1$ \\
\hline \multirow[t]{4}{*}{ Lactuca sativa $\mathrm{L}(n=12)$} & \multirow[t]{2}{*}{ Adults } & DIM & $5.0 \mathrm{E}-4$ & $4.0 \mathrm{E}-3$ & $8.0 \mathrm{E}-3$ & $7.0 \mathrm{E}-3$ & $3.0 \mathrm{E}-3$ & $3.3 \mathrm{E}-2$ \\
\hline & & HRI & 4.9E-1 & $3.0 \mathrm{E}-3$ & $1.5 \mathrm{E}-2$ & $3.8 \mathrm{E}-1$ & $8.3 \mathrm{E}-2$ & $1.1 \mathrm{E}-1$ \\
\hline & \multirow[t]{2}{*}{ Children } & DIM & $6.0 \mathrm{E}-4$ & $5.0 \mathrm{E}-3$ & $9.0 \mathrm{E}-3$ & $9.0 \mathrm{E}-3$ & $3.0 \mathrm{E}-3$ & $3.8 \mathrm{E}-2$ \\
\hline & & HRI & $5.6 \mathrm{E}-1$ & $3.0 \mathrm{E}-3$ & $1.8 \mathrm{E}-2$ & $4.3 \mathrm{E}-1$ & $9.5 \mathrm{E}-2$ & $1.3 \mathrm{E}-1$ \\
\hline
\end{tabular}

chain. In order to investigate the human HRI associated with wastewater-irrigated soils, it is essential to assess the PCF (Cui et al., 2004). The PCF were higher for $\mathrm{Cd}, \mathrm{Cu}$ and $\mathrm{Ni}$ than other metals and varied widely for plants species and also with sampling sites (Table 2). The high transfer values for $\mathrm{Cd}$, $\mathrm{Cu}$, and $\mathrm{Ni}$ from soil to plants indicate a strong accumulation of the respective metals by food crops, particularly by leafy vegetables. The results indicated that the PCF values were lower for $\mathrm{Cd}, \mathrm{Pb}$, and $\mathrm{Zn}$, and higher for $\mathrm{Cr}$ from those, as reported in literature for food crops (Liu et al., 2005), and may be due to the differences in soil properties. PCF values decreased with the increasing respective total metal concentrations in soils, indicating an inverse relationship between transfer factor and total metal concentrations. Such inverse relationships were also reported by Wang et al. (2006) for vegetables. The Pearson's correlation analysis showed that the relationship between soil metal concentrations and plants was strong particularly, for $\mathrm{Cd}, \mathrm{Cu}$, $\mathrm{Pb}$, and $\mathrm{Zn}$. The soil Cd concentrations showed a significant correlation with Cd in Zea mays, Brassica oleracea L. and Lactuca sativa L., while a negative relation was observed with Brassica juncea L. (Table 3). Similarly, a strong relationship was also detected between soil $\mathrm{Cu}$ concentrations and Brassica and Spinacia plants. In case of $\mathrm{Pb}$, the relationship was only significant for Brassica napus. The values for $\mathrm{Zn}$ in soils also showed significant relationships with plant $\mathrm{Zn}$ in Raphanus sativus L. and Brassica juncea L (Table 3).

In order to assess the health risk of any chemical pollutant, it is essential to estimate the level of exposure by quantifying the routes of exposure of a pollutant to the target organisms. There are various possible exposure pathways of pollutants to humans but the food chain is one of the most important pathways. As mentioned earlier, food crops were contaminated with heavy metals and the consumption of such foodstuffs can cause human health risks. In the study area, the vegetables and other foodstuffs produced are mostly sold in the local urban market, therefore, the average metal concentrations of food crops were used for calculation of the HRI. The data indicated that the HRI values were $<1$; therefore, the health risks of heavy metal exposure through the food chain was of no consequences and generally assumed to be safe. The estimated dietary intakes of $\mathrm{Cd}, \mathrm{Cr}$, $\mathrm{Cu}, \mathrm{Ni}, \mathrm{Pb}$, and $\mathrm{Zn}$ were far below the tolerable limits. Oral reference doses (RfD) for $\mathrm{Cd}, \mathrm{Cr}, \mathrm{Cu}, \mathrm{Ni}, \mathrm{Pb}$, and $\mathrm{Zn}$ are $1 \mathrm{E}-03$, 1.5E-0, 4E-2, 2E-2, 3.5E-3, and 0.3E-0 mg kg ${ }^{-1}$ day $^{-1}$, respectively (US-EPA, IRIS). In general, the RfD is an estimate of a daily exposure to the human population that is likely to be without an appreciable risk of deleterious effects during a lifetime (US-EPA, IRIS). The daily heavy metal intake for both adults, and children through the consumption of vegetables in this study was less than RfD limit set by the US-EPA, IRIS. The findings of this study regarding DIM and HRI suggest that the consumption of plants grown in wastewatercontaminated soils is nearly free of risks, but there are also other sources of metal exposures such as dust inhalation, dermal contact and ingestion (for children) of metal-contaminated soils, which were not included in this study.

\section{Conclusion}

The long term wastewater irrigation has led to contamination of soils and food crops in the study areas. Heavy metals were shown a substantial buildup with a significant increase over reference soils. The pollution load index values indicated that the wastewater-irrigated soils were moderately enriched with $\mathrm{Cr}, \mathrm{Cu}, \mathrm{Ni}, \mathrm{Pb}$, and $\mathrm{Zn}$, and strongly enriched with $\mathrm{Cd}$. 
Furthermore, it was concluded the wastewater-irrigated grown plants were contaminated with those heavy metals and exceeded the permissible limits for vegetables set by SEPA and WHO. However, the HRIs of the studied metals were $<1$, indicating that there is a relative absence of health risks associated with the ingestion of contaminated vegetables.

\section{Acknowledgments}

This research work was financially supported by the Ministry of Science and Technology (2007CB407301). Mr. Sardar Khan thanks HEC, Islamabad, Pakistan for awarding him $\mathrm{PhD}$ scholarship. We thank the anonymous reviewers for their valuable comments.

\section{References}

Bahemuka, T.E., Mubofu, E.B., 1999. Heavy metals in edible green vegetables grown along the sites of the Sinza and Msimbazi Rivers in Dar es Salaam, Tanzania. Food Chemistry 66, 63-66.

Bi, X., Feng, X., Yang, Y., Qiu, G., Li, G., Li, F., Liu, T., Fu, Z., Jin, Z., 2006. Environmental contamination of heavy metals from zinc smelting areas in Hezhang County, western Guizhou, China. Environment International 32, 883-890.

Chen, C.R., Xu, Z.H., Mathers, N.J., 2004. Soil carbon pools in adjacent natural and plantation forests of subtropical Australia. Soil Science Society of American Journal 68, 282-291.

Chen, Y., Wang, C., Wang, Z., 2005. Residues and source identification of persistent organic pollutants in farmland soils irrigated by effluents from biological treatment plants. Environment International 31, 778-783.

Cui, Y.J., Zhu, Y.G., Zhai, R.H., Chen, D.Y., Huang, Y.Z., Qiu, Y., Ling, J.Z., 2004. Transfer of metals from soil to vegetables in an area near a smelter in Nanning, China. Environment International 30, 785-791.

Cui, Y.J., Zhu, Y.G., Zhai, R., Huang, Y., Qiu, Y., Liang, J., 2005. Exposure to metal mixtures and human health impacts in a contaminated area in Nanning, China. Environment International 31, 784-790.

Ge, K.Y., 1992. The Status of Nutrient and Meal of Chinese in the 1990s. Beijing People's Hygiene Press. 415-434.

Ikeda, M., Zhang, Z.W., Shimbo, S., Watanabe, T., Nakatsuka, H., Moon, C.S., Matsuda-Inoguchi, N., Higashikawa, K., 2000. Urban population exposure to lead and cadmium in east and south-east Asia. Science of the Total Environment 249, 373-384.

Iyengar, V., Nair, P., 2000. Global outlook on nutrition and the environment: meeting the challenges of the next millennium. Science of the Total Environment 249, 331-346.

Khan, S., Cao, Q., Chen, B., Zhu, Y.G., 2006. Humic acids increase the phytoavailability of $\mathrm{Cd}$ and $\mathrm{Pb}$ to wheat plants cultivated in freshly spiked, contaminated soil. Journal of Soils Sediments 6, 236-242.

Liu, W.H., Zhao, J.Z., Ouyang, Z.Y., Soderlund, L., Liu, G.H., 2005. Impacts of sewage irrigation on heavy metals distribution and contamination in Beijing, China. Environment International 31, 805-812.

Lucho-Contantino, C.A., Álvarez-Suárez, M., Beltrán-Hernádez, R.I., PrietoGarcia, F., Poggi-Varaldo, H.M., 2005. A multivariate analysis of the accumulation and fractionation of major and trace elements in agricultural soils in Hidalgo State, Mexico irrigated with wastewater. Environment International 31, 313-323.

Ma, H.W., Hung, M.L., Chen, P.C., 2006. A systemic health risk assessment for the chromium cycle in Taiwan. Environment International, doi:10.1016/j.envint.2006.09.011.

Mapanda, F., Mangwayana, E.N., Nyamangara, J., Giller, K.E., 2005. The effect of long-term irrigation using wastewater on heavy metal contents of soils under vegetables in Harare, Zimbabwe. Agriculture. Ecosystem and Environment 107, 151-165.

Muchuweti, M., Birkett, J.W., Chinyanga, E., Zvauya, R., Scrimshaw, M.D., Lester, J.N., 2006. Heavy metal content of vegetables irrigated with mixture of wastewater and sewage sludge in Zimbabwe: implications for human health. Agriculture. Ecosystem and Environment 112, 41-48.

National Research Council (NRC), 1983. Risk Assessment in the Federal Government: Managing the Process. NAS-NRC Committee on the Institutional Means for Assessment of Risks to Public Health. National Academy Press, Washington, DC.

Nigam, R., Srivastava, S., Prakash, S., Srivastava, M.M., 2001. Cadmium mobilisation and plant availability-the impact of organic acids commonly exuded from roots. Plant and Soil 230, 107-113.

Rattan, R.K., Datta, S.P., Chhonkar, P.K., Suribabu, K., Singh, A.K., 2005. Long-term impact of irrigation with sewage effluents on heavy metal content in soils, crops and groundwater-a case study. Agriculture. Ecosystem and Environment 109, 310-322.

Rothenberg, S.E., Du, X., Zhu, Y.G., Jay, J.A., 2007. The impact of sewage irrigation on the uptake of mercury in corn plants (Zea mays) from suburban Beijing. Environmental Pollution 149, 246-251.

SEPA, 1995. Environmental quality standard for soils. State Environmental Protection Administration, China. GB15618-1995.

SEPA, 2005. The Limits of Pollutants in Food. State Environmental Protection Administration, China. GB2762-2005.

Sharma, R.K., Agrawal, M., Marshall, F., 2007. Heavy metal contamination of soil and vegetables in suburban areas of Varanasi, India. Ecotoxicology and Environment Safety, doi:10.1016/j.ecoenv.2005.11.007.

Singh, K.P., Mohan, D., Sinha, S., Dalwani, R., 2004. Impact assessment of treated/untreated wastewater toxicants discharged by sewage treatment plants on health, agricultural, and environmental quality in the wastewater disposal area. Chemosphere 55, 227-255.

Türkdogan, M.K., Fevzi, K., Kazim, K., Ilyas, T., Ismail, U., 2003. Heavy metals in soil, vegetables and fruits in the endemic upper gastrointestinal cancer region of Turkey. Environmental Toxicology and Pharmacology $13,175-179$.

United State, Environmental Protection Agency, Region 9, Preliminary remediation goals. http://www.epa.gov/region09/waste/sfind/prg.2002 (December, 2006).

US-EPA, IRIS. United States, Environmental Protection Agency, Integrated Risk Information System. http://www.epa.gov/iris/subst (December, 2006).

Wang, X., Sato, T., Xing, B., Tao, S., 2005. Health risks of heavy metals to the general public in Tianjin, China via consumption of vegetables and fish. Science of the Total Environment 350, 28-37.

Wang, G., Su, M.Y., Chen, Y.H., Lin, F.F., Luo, D., Gao, S.F., 2006. Transfer characteristics of cadmium and lead from soil to the edible parts of six vegetable species in southeastern China. Environmental Pollution 144, 127-135.

Wilson, B., Pyatt, F.B., 2007. Heavy metal dispersion, persistence, and bioaccumulation around an ancient copper mine situated in Anglesey. UK. Ecotoxicology and Environmental Safety 66, 224-231. 